\title{
KINERJA KEPOLISIAN RESOR SERUYAN DALAM MENANGANI KASUS NARKOBA JENIS PIL KOPLO DI KABUPATEN SERUYAN
}

\section{Performance of police Seruyan Resort in handling cases of drug type Koplo Pills in Seruyan District}

\section{Irwani* \\ Muhammad Rifa'i}

Universitas Muhammadiyah Palangkaraya, Palangka Raya, Central Kalimantan, Indonesia

email:

irwani@umpalangkaraya.ac.id

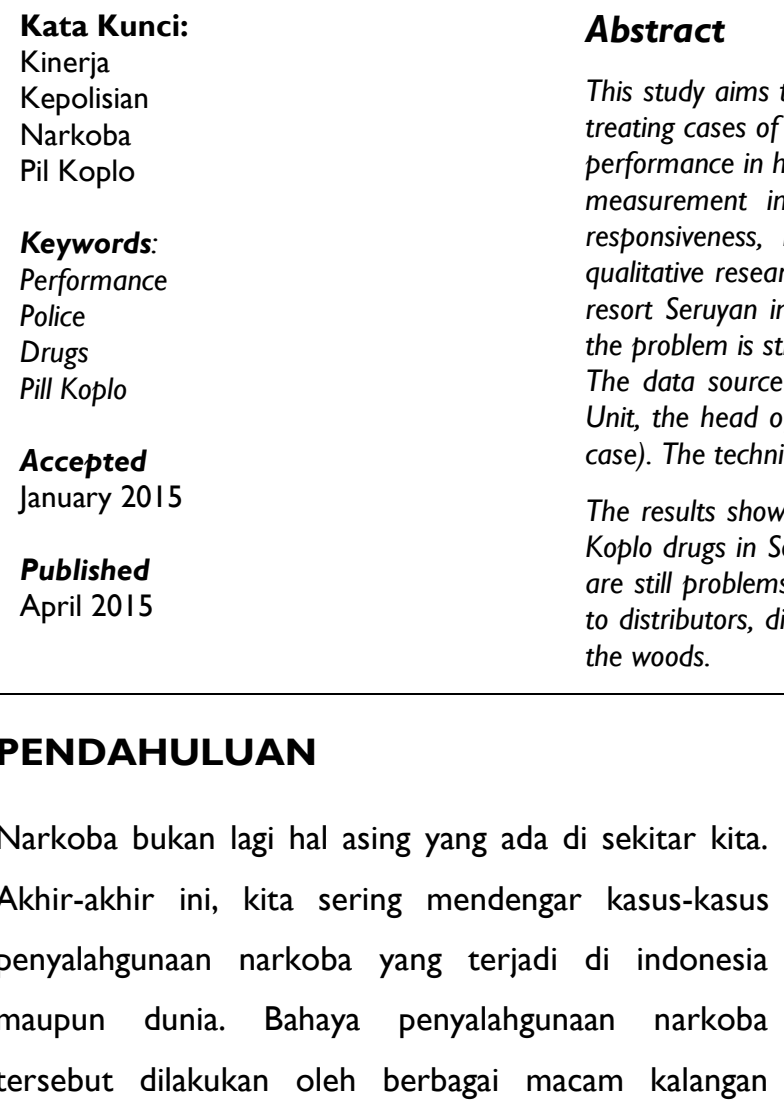

\begin{abstract}
Abstrak
Penelitian ini bertujuan untuk mengkaji dan mengetahui Kinerja Kepolisian Resor Seruyan Dalam Menangani Kasus Narkoba Jenis Pil Koplo Di Kabupaten Seruyan. Untuk mengetahui Kinerja Kepolisian Resor Seruyan Dalam Menangani Kasus Narkoba Jenis Pil Koplo Di Kabupaten Seruyan, saya menggunakan lima indikator pengukuran kinerja menurut Dwiyanto yaitu Produktivitas, Kualitas Pelayanan, Responsivitas, Responsibilitas, dan Akuntabilitas. Dalam melakukan penelitian ini, saya menggunakan metode penelitian kualitatif, metode ini dimaksudkan untuk menggambarkan Kinerja Kepolisian Resor Seruyan Dalam Menangani Kasus Narkoba Jenis Pil Koplo Di Kabupaten Seruyan. Dalam penelitian kualitatif masalah masih bersifat sementara dan akan berkembang atau berganti setelah peneliti berada di lapangan. Sumber data terdiri dari sumber primer (Kepala Satuan Reserse Kriminal, Kepala Satuan Reserse Narkoba, Masyarakat, dan Tersangka kasus obatobatan terlarang). Teknik mengumpukan data dengan wawancara, observasi, dan dokumentasi.

Hasil penelitian menunjukan bahwa Kinerja Kepolisian Resor Seruyan Dalam Menangani Kasus Narkoba Jenis Pil Koplo Di Kabupaten Seruyan dilihat dari kelima indikator menurut Dwiyanto, masih ada permasalahan yang dihadapi seperti adanya informasi penangkapan yang dibocorkan oleh pihak-pihak tertentu kepada pengedar, pengedar yang melarikan diri atau disembunyikan oleh keluarganya misalnya keluar kota atau di hutan.
\end{abstract}

\section{Abstract} treating cases of pill type Koplo drugs in Seruyan district. To find out Seruyan resort police handling cases of pill type Koplo drugs in Seruyan, I used five performance responsiveness, Responsibility, and accountability. In conducting this research, I use qualitative research methods, this method is meant to describe the performance of police resort Seruyan in dealing cases drug type Koplo pills in Seruyan. In qualitative research, The data source consists of the primary source (the head of the Criminal Investigation Unit, the head of the drug Reserve Unit, the community, and the suspected illegal drugs e). The technique is data-related with interviews, observations, and documentation.

showed that Seruyan resort police performance in handling cases of pill type

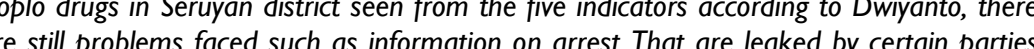
to distributors, distributors who flee or concealed by the family such as out of town or in
\end{abstract}

mulai dari pelajar, mahasiswa, sampai aparatur sipil negara.

Pada saat ini indonesia merupakan sasaran empuk bagi sindikat narkoba internasional untuk mengedarkan barang-barang tersebut, yang pada gilirannya menjadikan barang-barang ini dengan mudah diperoleh. Jaringan peredaran narkoba lebih terorganisir, bahkan 
sampai melibatkan orang-orang yang memiliki kekuasaan dan memiliki kedudukan. Bahaya narkoba tidak hanya terjadi dikota-kota besar tetapi sekarang peredaran narkoba sudah masuk ke kota-kota yang kecil bahkan sudah sampai pelosok-pelosok desa.

Di Kabupaten Seruyan peredaran narkoba akhir-akhir ini semakin marak. Jenis narkoba yang banyak beredar di Kabupaten Seruyan adalah obatobatan terlarang yaitu obat yang termasuk dalam daftar G (Gevaarlijk/berbahaya) yang sering disebut pil koplo atau nama lainnya carnophen atau zenit. Harga yang murah dan sangat mudah diperoleh di Kabupaten Seruyan dibandingkan barang lainnya seperti sabu-sabu dan ekstasi yang harganya mahal dan sulit diperoleh selain itu bisa tersandung masalah hukum yang berat jika tertangkap membuat obat-obatan yaitu pil koplo jenis carnophen atau zenit menjadi populer di wilayah Kabupaten Seruyan dari kalangan pelajar, buruh, sampai aparatur sipil negara. Harga yang murah berkisar antara 45-50 ribu rupiah per keping, maka obat-obatan ini mampu menjangkau seluruh lapisan masyarakat, mulai dari remaja, pedagang, kuli bangunan, buruh, bahkan pegawai negeri sipil. Sebagian dari mereka yaitu kuli bangunan mengatakan bahwa obat tersebut digunakan untuk bekerja karena dengan mengkonsumsi obat tersebut bekerja tidak akan terasa lelah. Melihat banyaknya pemakai yang berasal dari semua kalangan maka bisnis menjual pil koplo yaitu obat carnophen atau zenit menjadi salah satu pekerjaan primadona yang ada di Kabupaten Seruyan.

Pada umumnya penjual pil koplo jenis carnophen atau zenit di Kabupaten Seruyan adalah orang yang tidak memiliki pekerjaan atau pengangguran, karena tuntutan biaya hidup yang semakin tinggi membuat mereka menghalalkan berbagai cara dengan berjualan obat terlarang itu. Lemahnya aturan hukum yang berlaku di indonesia khususnya yang mengatur penyalahgunaan obat terlarang jenis pil koplo membuat peredaran obat ini semakin merajalela. Sampai saat ini belum ada aturan yang jelas dan undang-undangnya, salah satunya berupa pemberian sanksi terhadap para pelaku penyalahgunaan obat tersebut.

Kinerja berasal dari pengertian performance. Ada pula yang memberikan performance sebagai hasil kerja atau prestasi kerja. Namun, sebenarnya kinerja mempunyai makna yang lebih luas, bukan hanya hasil kerja, tetapi termasuk bagaimana proses pekerjaan itu berlangsung. Selanjutnnya, Prasetyo (200I:I) mengemukakan bahwa kinerja atau Performance adalah hasil kerja, sebuah proses manajemen atau organisasi secara keseluruhan, dimana hasil kerja tersebut harus dapat ditunjukkan buktinya secara konkrit dan dapat diukur dengan standar tolak ukur yang telah ditentukan.

Kinerja organisasi mempunyai banyak pengertian. Wibawa dan Atmosudirdjo (Pasolong, 2013:176) mengemukakan bahwa kinerja organisasi adalah sebagai efektifitas organisasi secara menyeluruh untuk kebutuhan yang ditetapkan dari setiap kelompok yang berkenaan melalui usaha-usaha yang sistemik dan meningkatkan kemampuan organisasi secara terus menerus untuk mencapai kebutuhannya secara efektif. Menurut Dwiyanto (dalam Pasolong, 2013:178) menjelaskan beberapa indikator yang digunakan untuk mengukur kinerja birokrasi publik, yaitu :
a. Produktivitas
b. Kualitas Pelayanan
C. Responsivitas
d. Responsibilitas
e. Akuntabilitas

Pengertian Narkoba

Narkoba singkatan dari narkotika, psikotropika, dan bahan adiktif berbahaya lainnya adalah bahan atau zat yang jika dimasukkan kedalam tubuh manusia baik secara oral/diminum, dihirup, maupun disuntikkan yang dapat mengubah pikiran, suasana hati atau perasaan, dan perilaku seseorang.

Faktor-faktor Penyebab Penyalahgunaan Narkotika
a. Faktor Keluarga
b. Faktor Kepribadian 
C. Faktor kelompok teman sebaya (peer group)

Pengertian Psikotropika Jenis Pil Koplo

Pil koplo disebut juga dengan carnophen atau pil zenit.

Berbicara tentang carnophen atau zenit merupakan sebuah nama merek dagang obat. Belakangan ini sering terjadi kasus penyalahgunaan obat yaitu carnohen atau zenit. Carnophen atau zenit masuk dalam obat golongan $\mathrm{G}$ narkotika serta dikategorikan sebagai obat keras yang pemanfaatannya harus dengan resep dokter.

Di dalam dunia farmasi, carnophen atau zenit sebenarnya adalah obat kimia yang bersifat racun. Namun jika dikonsumsi dalam dosis yang tepat bisa digunakan.

\section{METODOLOGI}

Dalam penelitian ini, peneliti menggunakan sistem pendekatan metode kualitatif, yang dimana metode kualitatif ini adalah sistem yang mendeskripsikan suatu masalah berupa kalimat-kalimat, sehingga peneliti dapat menjelaskan permasalahan yang akan diteliti dan diharapkan dengan melalui metode ini permasalahan dapat dilihat secara mendalam sehingga diperoleh gambaran mengenai Kinerja Kepolisian Resor Kabupaten Seruyan dalam menangani kasus narkoba.

\section{HASIL DAN PEMBAHASAN}

I. Produktifitas

Dari hasil wawancara kepada berbagai kalangan yaitu pihak kepolisian, pihak masyarakat, dan pihak tersangka terhadap kasus obat-obatan pil koplo jenis carnophen atau zenit ini tersangka penjual atau pengedar yang ditangkap terus bertambah.

2. Kualitas Pelayanan

Dari hasil wawancara kepada berbagai kalangan yaitu pihak kepolisian, pihak masyarakat, dan pihak tersangka terhadap kasus obat-obatan pil koplo jenis carnophen atau zenit ini maka kualitas pelayanan yang diberikan berupa penyebaran nomor telepon pihak kepolisian dan adanya tim buser.

3. Reponsivitas

Dari hasil wawancara kepada berbagai kalangan yaitu pihak kepolisian, pihak masyarakat, dan pihak tersangka terhadap kasus obat-obatan pil koplo jenis carnophen atau zenit ini maka respon pihak kepolisian cukup cepat tanggap berkat informasi pelaku atau pengedar yang diberikan masyarakat atau tim buser sangat akurat.

4. Responsibilitas

Dari hasil wawancara kepada berbagai kalangan yaitu pihak kepolisian terhadap kasus obat-obatan pil koplo jenis carnophen atau zenit ini maka aturan yang dipakai adalah Peraturan Undang-Undang Nomor 36 Tahun 2009 Pasal 197 ayat (I) tentang Kesehatan.

5. Akuntabilitas

Dari hasil wawancara kepada berbagai kalangan yaitu pihak kepolisian dan masyarakat terhadap kasus obat-obatan pil koplo jenis carnophen atau zenit ini maka tanggup jawab pihak kepolisian dalam pemberantasan obat terlarang ini berupa pemasangan foto-foto tersangka di jalan raya serta melakukan sosialisasi kepada masyarakat dan sekolah-sekolah tentang bahaya penyalahgunaan obat tersebut.

\section{KESIMPULAN}

Berdasarkan hasil pembahasan dalam penelitian ini, dapat dibuat kesimpulan tentang Kinerja Kepolisian Resor Seruyan Dalam Menangani Kasus Narkoba Jenis Pil Koplo Di Kabupaten Seruyan sudah cukup bagus karena :

I. Produktivitas

Kinerja Kepolisian Resor Seruyan dalam menangani kasus obat-obatan jenis pil koplo dapat dikatakan masih sangat kurang.

2. Kualitas Pelayanan 
Berdasarkan hasil penelitian, dapat diketahui bahwa pelayanan yang diberikan oleh pihak Kepolisian Resor Seruyan dalam menangani kasus obat-obatan jenis pil koplo sudah cukup bagus.

3. Responsivitas

Responsivitas Kepolisian Resor Seruyan dalam menangani kasus obat-obatan jenis pil koplo sudah dikatakan cukup bagus.

4. Responsibilitas

Responsibilitas Kepolisian Resor Seruyan sudah dikatakan cukup bagus.

5. Akuntabilitas

Akuntabilitas pihak Kepolisian Resor Seruyan dapat dikatakan cukup bagus

\section{REFERENSI}

Badan Narkotika Nasional (BNN) Republik Indonesia. Mahasiswa dan Bahaya Narkotika.

Darmono. 2006. Toksikologi Narkoba Dan Alkohol. Universitas Indonesia: Jakarta

Fahmi, Irham. 20I4. Manajemen Teori, Kasus, dan Solusi. CV. Alfabeta: Bandung.

Hamzah, Andi dan R.M. Surachman. 1994. Kejahatan Narkotika Dan Psikotropika. Sinar Grafika: Jakarta

Kaswan, 2012. Coaching Dan Mentoring Untuk Pengembangan SDM Dan Peningkatan Kinerja Organisasi. CV. Alfabeta:Bandung.

Ketut Ritiasa, Ketut dan Sitomorang, Hulman, 2007. Info Obat Indonesia. Info Obat Indonesia: Jl. Percetakan Negara 23 Jakarta

Pasolong, Harbani, 2014. Metode Penelitian Administrasi Publik. CV. Alfabeta:

Pasolong, Harbani , 2007. Teori Administrasi Publik. CV. Alfabeta: Bandung

Sugiyono, 2013. Metode Penelitian Kualitatif. CV. Alfabeta: Bandung Torang,
Syamsir, 2014. Organisasi dan Manajemen (Perilaku, Struktur, Budaya, \& Perubahan Organisasi). CV. Alfabeta: Bandung Utami,

Prini,Sanjaya, Ahmad dan Nazlatunihayah, 200l. Katakan Tidak Pada Narkoba. CV. Sarana Penunjang Pendidikan; Bandung.

Prasetyo, Irawan. 200I. Analisis kinerja: panduan praktis untuk menganalisis kinerja Organisasi, kinerja proses dan kinerja pegawai. Jakarta: LAN. 